\title{
Analysis of Factors Influencing the College Choice Decisions of NCAA Division II Elite Track and Field Athletes
}

\author{
${ }^{1}$ Jon Lim, ${ }^{2}$ Lisa Paulson, ${ }^{3}$ Bryan Romsa, ${ }^{4}$ Hal J. Walker, ${ }^{5}$ Katelyn Romsa \\ ${ }^{1}$ Associate Professor, Sport Management Graduate and Undergraduate Programs \\ Minnesota State University, Mankato \\ ${ }^{2}$ Career Education Corporation \\ ${ }^{3}$ South Dakota State University \\ ${ }^{4}$ Elon University \\ ${ }^{5}$ South Dakota State University
}

\begin{abstract}
The student-athlete college selection process is a major decision impacting their future academic and athletic success. A better understanding of factors influencing this selection process will aid intercollegiate athletic programs in recruiting and retaining the highest caliber athletes possible. This study examined the factors influencing the college choice decisions of NCAA Division II elite track and field athletes across the United States. The participants were 320 athletes who represented 78 NCAA Division II institutions located in eight regions across the United States. This article discusses the most important factors involved in the college selection process of NCAA Division II elite track and field athletes. Practitioners may use this information to effectively shape their recruiting and marketing practices.
\end{abstract}

Keywords: Student-Athlete Recruiting; Institutional Marketing; College Choice Factors; College Selection Process.

\section{INTRODUCTION}

The participation rates in National Collegiate Athletic Association (NCAA) sports have shown a steady and continual climb over the past three decades and are at an all-time high for both male and female student-athletes (NCAA, 2016b). According to the recent NCAA Sports Sponsorship and Participation Rates Report, there were a total of 482,533 student-athletes competing in 24 sports at the Division I, II, and III, with the number of teams competing in NCAA championship sponsored sports continued to rise to a record of 19,326 during 2014-15 academic year (NCAA, 2015). Considering the ever-increasing number of collegiate student-athletes, they are an important part of higher education and intercollegiate athletics are an essential aspect of American culture (Upthegrove, Roscigno, \& Charles, 1999).

The NCAA Sports Sponsorship and Participation Rates Report also revealed that men's and women's indoor and outdoor track and field was in the top five for participation rates in 2014-15 as shown in Tables 1 and 2 (NCAA, 2015). For instance, women's outdoor track and field has had the most female student-athletes in the NCAA than any other women's sport since the NCAA started collecting this data in 1981-82. Also, women's indoor track and field had the third highest participation rates after soccer in 2014-15. Additionally, men's outdoor track and field had the third highest and men's indoor track and field had fourth highest participation after football and baseball in 2014-15 (NCAA, 2015). Furthermore, the NCAA women's sports that added the highest number of female teams in 2014-15 was outdoor track and field and lacrosse with 31 new teams in each, followed by indoor track and field with 21 new teams. The men's sport that added the highest number of male teams in 2014-15 was outdoor indoor track and field with 29 new teams. The men's sport that has been added the most since 1981-82 is indoor track and field with 504 new teams (NCAA, 2015). The substantial increase in the number of new teams for both NCAA female and male track and field has created more competition and pressure on NCAA athletic programs recruiting quality track and field athletes. 
Table1. Women's Top Five Highest Participation Sports

\begin{tabular}{|l|l|l|l|l|l|}
\hline Division & Track, Outdoor & Soccer & Track, Indoor & Volleyball & Basketball \\
\hline I & 13,075 & 8,963 & 12,816 & 5,165 & 4,984 \\
\hline II & 6,962 & 7,229 & 5,785 & 5,011 & 4,937 \\
\hline III & 8,760 & 10,803 & 8,019 & 6,850 & 6,668 \\
\hline Total & 28,797 & 26,995 & 26,620 & 17,026 & 16,589 \\
\hline
\end{tabular}

Note. Adapted from "NCAA Sports Sponsorship and Participation Rates Report." 2015, October, http://www. ncaapublications.com

Table2. Men's Top Five Highest Participation Sports

\begin{tabular}{|l|l|l|l|l|l|}
\hline Division & Football & Baseball & Track, Indoor & Track, Outdoor & Soccer \\
\hline I & 27,873 & 10,396 & 11,067 & 10,174 & 5,738 \\
\hline II & 19,306 & 10,522 & 7,173 & 5,709 & 6,551 \\
\hline III & 25,609 & 13,280 & 9,937 & 9,204 & 12,188 \\
\hline Total & 72,788 & 34,198 & 28,177 & 25,087 & 24,477 \\
\hline
\end{tabular}

Note. Adapted from "NCAA Sports Sponsorship and Participation Rates Report." 2015, October, http://www.nc aapublications.com

The success of collegiate athletic teams can positively influence institutional academic reputation (Stinson \& Howard, 2007), donations from alumnae and local boosters (Stinson \& Howard, 2004; Tucker, 2004), admission applications (Toma \& Cross, 1998), and revenues from television coverage (Fulks, 2000). Consequently, the desire to create winning teams has become a phenomenon in intercollegiate athletics. Recruitment of top caliber athletes is vital to the success of any inter collegiate athletic programs. As intercollegiate athletic programs increase their recruitment efforts to attract top student-athletes, it has become increasingly important to understand why student-athletes select one institution over another. Therefore, it is essential that those involved in the recruitment of student-athletes understand the factors influencing the college choice decisions of student-athletes. A better understanding of factors influencing this selection process will aid intercollegiate athletic programs in recruiting and retaining the highest caliber athletes possible.

Prospective student-athletes are drawn to colleges and universities for a variety of reasons. There is a complexity of influences present in a student-athlete's college selection process. The overall body of published literature regarding factors influencing a student-athlete's college selection process is limited but continues to grow. Factors that appear to have the most influence in an athlete's choice of which college or university to attend include (a) academics (Bukowski, 1995; Letawsky, Schneider, Pedersen, \& Palmer, 2003; Mathes \& Gurney, 1985; Pauline, 2010; Skaff, 1992); (b) the opportunity to play (Bouldin, Stahura, \& Greenwood, 2004; Pauline et al., 2004); (c) amount of financial aid (e.g., athletic scholarship, cost to attend college, amount of scholarship, and availability for extra aid; Doyle \& Gaeth, 1990; Kankey \& Quarterman, 2007; Pauline, 2012); and (d) head coach (Klenosky, Templin, \& Troutman, 2001; Letawsky et al., 2003). A number of previous research studies collaboratively revealed that the most influential factor in the college selection process of studentathletes is the degree program offered (Goss, Jubenville, \& Orejan, 2006; Kankey \& Quarterman, 2007; Letawsky, Palmer, \& Schneider, 2005; Letawsky et al., 2003). But, other research has found that athletic factors to be the most important factor in the college selection process (Bouldin et al., 2004; Crowley, 2011; Gabert et al., 1999; Klenosky et al., 2001; Pauline, 2010;).

Due to the differences in the rank order of importance of college choice factors, and the difference between sport and divisions there is a need to examine how NCAA Division II track and field athletes choose their institution. In addition, the majority of prior studies on college choice factors have utilized athletes at NCAA Division I universities. Therefore, the purpose of this study was to examine the factors influencing the college choice decisions of NCAA Division II elite track and field athletes across the United States.

\section{The ReCruitMent OF STUdent-ATHLETES AT NCAA Division II}

During the 2016-17 academic year, there are currently 307 colleges and universities classified as NCAA Division II competing in 24 conferences while additional 13 schools are going through a process of getting the membership (NCAA, 2016c). In order to attract student-athletes to Division II programs, recruiters need to better understand the influencing factors involved in the athlete's college choice and Division II institutions must effectively market and promote their academic and athletic 
programs to prospective student-athletes in the efforts to distinguish themselves against their competition: Division I and Division III.

Established as the compromise among Division I and Division III, Division II appeals to studentathletes as a distinct medium that embodies the assets of both levels. For example, Division II athletes miss fewer classes and play most of their contests close to home due to an emphasis on regional opportunity for approximately every seven student-athletes (NCAA, 2016c). The academic and athletic balance found in Division II has led to 95\% of Division II student-athletes stating that they would recommend Division II to prospective student-athletes and consistently graduated at rates higher than their student body counterparts (NCAA, 2016c).

With both the rapid advancement and necessity of recruiting, intercollegiate coaches have acknowledged recruiting as the most difficult aspect of their jobs (Smith, 2005). Recruiting strategies practiced are constantly changing and the need for innovative methods is crucial for the recruitment and retention of student-athletes. To recruit, secure, and retain elite athletes at the Division II level, sound recruiting mechanisms must constantly be updated and refined. The intense and crucial nature of recruiting produces the need for an essential understanding of the influential college choice factors among student-athletes (Gabert, Hale, \& Montalvo, 1999).

To successfully promote Division II institutions to elite athletes, the many influences that underlie the college selection process need analysis and clarity. While recruiting methods continue to acquire constant updates and refinement, Division II institutions must effectively promote themselves to target top athletes. The college selection process of prospective student-athletes depends on several influencing factors. The complexity and reasoning behind these influences has long sparked the interest of college recruiters, coaches, admissions representatives, and colleges and universities as a whole.

\section{Identified College Selection Factors among Student- AthleteS}

Some recent studies indicated that prospective student-athletes are drawn to colleges and universities for a variety of reasons. Previous research emphasizes the similarities, differences, and the complexity of influences present in a student-athletes' college choice process. The research consistently demonstrated the importance of both academic and athletic factors in the college choice decision. A number of previous research studies have revealed the most influential factor in the college selection process of student-athletes as the degree program offered (Goss et al., 2006; Kankey \& Quarterman, 2007; Letawsky et al., 2005; Letawsky et al., 2003). However, other previous studies have found that athletic factors were the most influential factor in the college selection process (Bouldin et al., 2004; Crowley, 2011; Gabert et al., 1999; Klenosky et al., 2001; Pauline, 2010).

In Kankey and Quarterman's (2007) study, the top five college choice factors in rank order as availability of major/academic program, head coach, career opportunities after graduation, social atmosphere of the team, and amount of financial aid in their study of 196 NCAA Division I softball players. Moreover, Letawsky et al. (2005) found similar results from 126 first-year student-athletes enrolled at an NCAA Division I middle-sized University and found the top five most influencing factors in rank order were degree program options, head coach, academic support services, community, and the school's sports traditions. Interestingly, Pauline (2012) found that top five college choice influencing factors in rank order were academic program or major, academic reputation, career opportunities after graduation, overall reputation of the university, and social atmosphere of the team, with investigating 982 first-year male and female soccer players from Division I, II, and III.

Earlier research conducted by Gabert et al. (1999) revealed that the most influential factors in the college selection process of student-athletes were head coach, location of school, opportunity to play, degree programs, and academic support services in their study of 246 freshmen from five southern universities. The study also found that Division I student-athletes viewed academic support services as the most important factor while Division II student-athletes considered location of school as the top factor. Division III student-athletes chose head coach as the most important factor. Also, Bouldin et al. (2004) found that the five most influential factors in the college selection process were the opportunity to play, impression made by the head coach, desire to play for a winning team, reputation of the head coach, and percentage of scholarship offered in their sample of 98 Division I baseball players. Additionally, an exploratory means-end theory study conducted by Klenosky et al. (2001) revealed that the five most important factors were the coaches and coaching staff, schedule, facilities, 
open spot, and location in their study of 27 NCAA Division I football players. Furthermore, Crowley (2011) conducted a study to identify college choice factors using 385 male and female track and field student-athletes from 34 teams of NCAA Division I Historically Black Colleges and Universities and found the top factors to be opportunity to play, degree program, academic support, college head coach, and location of school.

Comparing across all three divisions, academic factors have been found to be the most important for all divisions while Division I and II student-athletes perceived coaching factor was significantly more important than Division III (Pauline, 2012). Findings from previous investigations involving NCAA Division III athletes have found academic factors to have the most impact on their college selection (Bukowski, 1995; Pauline, 2010). The importance of academics is consistent with the NCAA Division III philosophy (NCAA, 2016a). While many NCAA Division I student-athletes do value academics, almost two of every three NCAA Division I student-athletes consider themselves more as athletes than as students (Wieberg, 2008). Vermillion and Spears (2012) found the most important choice factor to be the coaching staff from student-athlete respondents from all sports funded by a Division I athletic department at an urban university. This perception of NCAA Division I student-athletes to consider themselves more as athletes than students is also consistent with the NCAA Division I athletic programs philosophy (NCAA, 2016a).

\section{GENDER COMPARISON}

Gabert et al. (1999) discovered that male and female student-athletes' choice of school was influenced in similar ways. Precisely, both males and females chose the head coach as the top influential factor and the opportunity to play as the third most important factor. Also notable was that of the top five factors, only two out of the five were related to athletic participation.

Similarly, Goss et al. (2006) found that slight gender differences existed in the top factors influencing the college choice decision. Among the top five factors noted with males and females, males chose the most important factor as head coach while females chose degree programs. Letawsky et al. (2005) discovered that males chose degree program options as the most significant factor, while females chose academic support services. Both males and females indicated the same top four factors, but in a different order of influence. Interestingly, three of the top five factors indicated by males were related to campus environment and two were related to athletics. In opposition, females only indicated that one of the top five factors was related to athletics (head coach). Lastly, Pauline (2012) compared firstyear male and female student-athletes from the same sport across three NCAA division. Pauline (2012) found that academic factors were most important to first-year male and female soccer players across all three NCAA divisions. However, there were significant differences between male and female soccer players among major categories of the survey. Athletic and coaching factors were viewed as more influential in the college selection process for male soccer players than female players. This result somewhat aligns with the findings Pauline (2010) who also found males to report coaches and endorse athletic factors as more a more important factor than females.

While minor gender differences existed in the most influential factors indicated, the similarities found among genders were more prevalent. The determination of gender differences in college selection factors is important to understand so coaches can tailor their recruiting practices according to gender.

\section{THEORETICAL FRAMEWORK}

A theoretical framework regarding the decision-making process of college student-athletes by specific sport teams has not yet been established. As a result, the conceptual framework for this investigation was guided by a decision-making model developed by Hossler and Gallagher (1987). Hossler and Gallagher's model is composed of three stages that individuals progress through during the college selection process (predisposition, search, and choice). The first stage, predisposition, focuses on characteristics of the students (e.g., family background, academic performance, peer group, extracurricular high school experiences) and whether or not they wish to continue their formal education beyond high school or pursue other options. The second stage, search, involves the search process and the way that students and institutions seek out each other. During this stage, students narrow their institution options and evaluate whether attending college is the right fit based upon the attributes and values they feel to be most important. Students also begin to explore as well as eliminate their options of colleges and universities by engaging in many interactions with various institutions. The third stage, choice stage, focuses on the choice process where students take the information they have gathered from the search phase and then make a decision on which school to 
attend based on their own evaluation criteria. Students enter this stage when applying to a select list or limited number of institutions. Students complete this stage when they decide which university to attend. According to Hossler and Gallagher (1987), it is during this stage when students consider multiple factors such as the cost, location, and academic reputation of the institutions they are considering. The choice stage of the college selection process was the focus for this investigation.

\section{Methodology}

\subsection{Participants}

A total of 320 athletes (162 men, 158 women; between the ages of 18 and 27, $M=21.1$ years, $S D=1.7$ ) volunteered to participate in the study, yielding a return rate of $80 \%$. The participants were ethnically diverse, with 57.2\% Caucasian and 42.8\% ethnic minorities including African-Americans, Asians, Hispanics, and athletes with multiethnic backgrounds. The participants represented 78 NCAA Division II institutions located in eight regions across the United States. The eight regions are categorized as East, Great Lakes, Northeast, North Central, South, South Central, Southeast, and West.

\subsection{Measures}

The Student Athlete College Choice Profile Survey (SACCPS) was utilized to assess factors influencing the college choice decisions of NCAA Division II elite track and field athletes (Gabert et al., 1999). This SACCPS instrument has been used to study college choice factors for athletes at both NCAA Division I and II programs (Crowley, 2004; Goss, Jubenville, \& Orejan, 2006; Letawsky, Palmer, \& Schneider, 2005; Letawsky et al., 2003). The SACCPS instrument has demonstrated adequate reliability and validity (Gabert et al., 1999; Crowley, 2004). For this study, slight modifications were made with college selection factors, more specific to NCAA Division II track and field. The reliability (Cronbach's alpha) for this study was .86, which is considered as an acceptable level (Nunnally and Bernstein, 1994).

The survey was divided into three sections: 1) college selection factors, 2) additional information and 3) demographic information. Section one contained 24 college selection factors such as degree program offered, head coach and coaching staff, location of school, and size of school. Participants were asked to rank these factors using a five-point Likert scale ranging from 1 (No Influence) to 5 (Very High Influence). Section two provided an area to list other factors of influence not mentioned in section one. Section three included demographic information such as name of college, age, gender, ethnicity, primary event, athletic and financial aid, and All-American status.

\subsection{Procedures}

Approval was first obtained from the university institutional review board to conduct this study. Next, permission was obtained permission from the NCAA to collect data at the NCAA Division II Indoor Track and Field Championships. The athletic director introduced the researcher at the coaches' meeting. The researcher described the purpose of the study, instructions, the voluntary nature, consent, and confidentiality. Data for this study was collected at the student-athlete banquet on the evening prior to competition at the 2008 NCAA Division II Indoor Track and Field Championships. Surveys were distributed to one representative from each school in a sealed survey package. A coaches' consent form and cover letter were included in the survey package explaining the procedures, voluntary participation, confidentiality, benefits, and that each participating athlete was at least 18 years of age. Athletes completed the surveys on a voluntary and anonymous basis and immediately returned the surveys in the sealed envelope. Completed surveys were collected by the researcher at the conclusion of the banquet.

\subsection{Statistical Analysis}

Descriptive statistics (percentages, frequency distributions, means, ranges, and standard deviations) were utilized to describe the demographic characteristics of the participants. Initially the internal consistency (Cronbach's alpha) of the modified SACCPS instrument was examined to ensure that it is reliable for the present sample. Nunnally and Bernstein's (1994) recommended alpha value of .70 was used to evaluate the internal consistency of the instrument. Means and standard deviations were utilized to compare factors influencing college choice decisions. Additionally, t-tests were conducted to determine significant differences in college choice factors by gender. Statistical significance was accepted at an alpha level of $\mathrm{p}<.05$. 


\section{RESULTS}

A total of 320 completed surveys were used for data analysis for a return rate of $80 \%$. The respondents consisted of $162(50.6 \%)$ men and 158 (49.4\%) women who ranged in age from 18-27 years $(M=21.08, S D=1.66)$. Respondents highly represented the North Central $(27.8 \%)$, South Central (21.6\%), and Great Lakes (17.8\%) regions. At the time of the study, 287 (89.7\%) respondents were athletic scholarship recipients. In addition, there were $180(56.3 \%)$ respondents who considered attending a Division I institution and $42(13.1 \%)$ who considered attending a Division III institution.

As shown in Table 3, the five most influential factors in the college selection process were the opportunity to compete $(M=4.30)$, head coach and coaching staff $(M=3.92)$, athletic scholarship $(M$ $=3.72)$, degree programs offered $(M=3.64)$, and athletic team atmosphere $(M=3.47)$. Of these five factors, four were directly related to athletics while one was related to academics.

Table3. College Selection Factors

\begin{tabular}{|l|l|l|l|l|l|l|}
\hline & \multicolumn{2}{|c|}{ Overall } & \multicolumn{2}{c|}{ Female } & \multicolumn{2}{c|}{ Male } \\
\hline College Choice Factor & Mean & SD & Mean & SD & Mean & SD \\
\hline Opportunity to Compete & 4.297 & 0.990 & 4.310 & 0.930 & 4.284 & 1.048 \\
\hline Head Coach and Coaching Staff & 3.922 & 1.063 & 3.898 & 0.995 & 3.944 & 1.127 \\
\hline Athletic Scholarship & 3.724 & 1.346 & 3.866 & 1.271 & 3.586 & 1.404 \\
\hline Degree Programs Offered* & 3.641 & 1.136 & 3.886 & 0.944 & 3.401 & 1.253 \\
\hline Athletic Team Atmosphere* & 3.466 & 1.185 & 3.620 & 1.050 & 3.315 & 1.288 \\
\hline Cost of Tuition* & 3.385 & 1.287 & 3.632 & 1.190 & 3.148 & 1.334 \\
\hline Location of School & 3.384 & 1.211 & 3.456 & 1.132 & 3.315 & 1.283 \\
\hline History of Athletic Program & 3.281 & 1.273 & 3.234 & 1.185 & 3.327 & 1.355 \\
\hline Athletic Traditions & 3.225 & 1.262 & 3.278 & 1.188 & 3.173 & 1.331 \\
\hline Athletic Facilities & 3.197 & 1.153 & 3.280 & 1.073 & 3.117 & 1.223 \\
\hline Academic Support Services* & 3.174 & 1.680 & 3.436 & 2.017 & 2.919 & 1.225 \\
\hline Official Campus Recruiting Visit* & 3.054 & 1.385 & 3.312 & 1.334 & 2.800 & 1.391 \\
\hline Size of School* & 3.013 & 1.203 & 3.241 & 1.120 & 2.789 & 1.242 \\
\hline Chance to Travel & 2.997 & 1.276 & 2.924 & 1.239 & 3.068 & 1.310 \\
\hline Community* & 2.978 & 1.124 & 3.215 & 1.061 & 2.747 & 1.138 \\
\hline Campus Social Life* & 2.887 & 1.162 & 3.051 & 1.150 & 2.725 & 1.154 \\
\hline Unofficial Campus Visit* & 2.806 & 1.274 & 3.063 & 1.250 & 2.553 & 1.250 \\
\hline On Campus Dorms* & 2.715 & 1.280 & 2.867 & 1.277 & 2.565 & 1.269 \\
\hline Family Members* & 2.615 & 1.381 & 2.853 & 1.329 & 2.385 & 1.397 \\
\hline Spiritual Guidance & 2.524 & 1.254 & 2.633 & 1.248 & 2.415 & 1.254 \\
\hline Teams in Conference & 2.500 & 1.201 & 2.462 & 1.132 & 2.537 & 1.267 \\
\hline Win/Loss Record & 2.423 & 1.305 & 2.367 & 1.202 & 2.478 & 1.401 \\
\hline High School Teammates' College Choice & 1.832 & 1.075 & 1.772 & 1.021 & 1.892 & 1.126 \\
\hline TV Exposure & 1.580 & 0.904 & 1.529 & 0.821 & 1.630 & 0.977 \\
\hline
\end{tabular}

Note. *Significant difference at the $p<0.05$ level

For females, the top five factors were opportunity to compete $(M=4.31)$, head coach and coaching staff $(M=3.90)$, degree programs offered $(M=3.89)$, athletic scholarship $(M=3.87)$, and cost of tuition $(M=3.63)$. Of these factors, three were related to athletics whereas two were related to academics. Four factors indicated by males paralleled those for females, but in a different order of importance. For males, the top five factors were opportunity to compete $(M=4.28)$, head coach and coaching staff $(M=3.94)$, athletic scholarship $(M=3.59)$, degree programs offered $(M=3.40)$, and history of athletic program $(M=3.33)$. Of these factors, four were related to athletics whereas only one was related to academics.

Of the 24 influential college selection factors, significant gender differences were found among 11 factors. Females ranked the importance of all 11 factors higher in relation to males. As shown in Table 1, the factors with a significant difference were: degree programs offered, size of school, academic support services, on campus dorms, unofficial campus visit, family members, athletic team atmosphere, cost of tuition, community, and campus social life. Only two of these factors (degree program offered and athletic team atmosphere) were found in the overall top five most important factors. 


\section{DisCUSSION AND CONCLUSIONS}

The results of this study indicated that the most important factor involved in the college selection process of NCAA Division II elite track and field athletes was the opportunity to compete. Coaches should be aware that Division II provides the most championship opportunities among the divisions with a 7.54-1 ratio (NCAA, 2016c). The opportunities to compete at a championship level may be used to recruit student athletes. These athletes may have a chance to compete earlier in their career, and they have a greater probability to compete at a championship level. Other influential factors in order of importance were the head coach and coaching staff, athletic scholarship, degree programs offered, and athletic team atmosphere.

The distinctive findings of this study presented both insight and contrast to previous research. Interestingly, the findings from this study do not coincide with the general balance of athletic and academic factors found in earlier studies by Kankey and Quarterman (2007). Four of the top five factors were directly related to athletics, while only one was related to academics. Not surprisingly, the results of this study suggest that Division II elite athletes also viewed athletic factors as the prominent in their ultimate college choice. Furthermore, these findings indicate that it may be important for the coaching staff to be aware of the importance of their interactions with studentathletes during the recruiting process, and the recruit's interactions with current athletes as they attempt to gage the team atmosphere.

Identical to the results of Bouldin et al. (2004), Gabert et al. (1999), and Klenosky et al. (2001), the opportunity to compete, and head coach and coaching staff were the top three influential factors. It may be concluded that at the Division II level, the importance of athletic competition has never been greater. Elite athletes have the predetermined notion to choose an institution that will fulfill their athletic goals and expectations. Additionally, because the success of an athlete is often measured and recognized by the role of the coach, intercollegiate coaches leave a lasting impression on prospective student-athletes. This suggests that the college choice decision heavily relies on whether or not the athlete is able to envision him or herself having a comfortable and positive relationship with the coach.

Furthermore, the results of this study indicated that males and females matched four of the top five influencing factors but in a slightly different order of importance. Additionally, males and females displayed a significant difference among 11 college choice factors. Females placed a greater emphasis on all 11 of the factors when compared to males. Specifically, females were slightly more focused on academic factors. These results paralleled both the findings of Gabert et al. (1999) and Goss et al. (2006), who found that academic factors had a greater influence for female student-athletes. Coaches of female track and field teams may want to involve academic components as they are recruiting student-athletes. Pauline (2012), suggests that the "coaching staff should identify the desired major or academic area of interest of their potential student-athletes. They should arrange for the students to meet with faculty from this area during the recruiting visit, sit in on classes, tour the academic facilities, gather information about the academic requirements for the major, and career opportunities upon graduation."

Based on our findings in this study, coaches of NCAA Division II elite track and field athletes should review the academic strengths of their institution such as degree programs offered but ought to emphasize the athletic resources available to their athletes. They must recognize track and field athletes want to know what opportunities they will have to compete as an elite athlete on their team. In addition, coaches must recognize that their coaching style and personality have a great impact on college choice of elite track and field athletes. Therefore, every attempt should be made to build rapport and recruit athletes who fit with and accept the coaching staff's personality and style. Coaches should be aware of the diverse factors influencing a student-athlete's college selection as well as attempt to maximize financial aid support as best they can to match a recruit's expressed interests. These factors should be incorporated into the coaching staffs overall recruiting strategy.

This investigation has increased the understanding of factors influencing the college choice of NCAA Division II elite track and field athletes across the United States. Based on the results of this study, the opportunity to compete and the head coach and coaching staff had the greatest influence on elite track and field male and female athletes when deciding what university to attend. Other top influential factors included athletic scholarship, degree programs offered, and athletic team atmosphere, and 
history of athletic program. Of these factors, five were directly related to athletics while only one was related to academics. For those individuals (i.e., head coaches, assistant coaches, and administrators) involved with the recruitment of NCAA Division II elite track and field athletes being aware of such factors will help them to be more successful in the recruitment process.

While recruiting efforts are commonly targeted with a balance between academic and athletic factors, the athletic dynamic needs a greater emphasis to recruit and retain elite track and field athletes at the Division II level. If recruiters are able to update and refine their recruiting methods to better accommodate the athletic interests of elite athletes, Division II institutions can distinguish themselves from Division I and effectively promote themselves to target top athletes.

\section{LiMitaTIONS AND FUTURE DIRECTIONS}

A limitation of this investigation was that it only examined track and field athletes at NCAA Division II institutions. Despite the limitations, this investigation provides some useful findings and recommendations for future investigations. The first recommendation is that more qualitative studies are needed to uncover influential factors related to the college selection process that are not completely addressed by the current survey or previous survey research. Future investigations could also examine prospective student-athletes during the second phase of Hossler and Gallagher's (1987) college selection process when they are involved in the recruiting and decision process, rather than after they have chosen an institution. Lastly, studies analyzing the impact of involving academicrelated activities during the recruiting process and campus visits is another area where for future studies are needed.

\section{REFERENCES}

[1] Bouldin, C., Stahura, K., \& Greenwood, M. (2004). Selection criteria for division I baseball play ers: An analysis of the recruiting process. Annual Applied Research in Coaching \& Athletics, 19, 137-165.

[2] Brown, G. T. (2007). Research reveals more about athletes' college choice. NCAA News, 44(10), 14.

[3] Castle, J., \& Kostelnik, R. (2011). The effects of an institution's athletic success on the future fresh men application pool at NCAA Division II universities. Journal of Issues in Inter collegiate Athletics, 4(1), 411-427.

[4] Crowley, J. N. (2006). In the arena: The NCAA's first century. Indianapolis, Indiana: The NCAA.

[5] Doyle, C. A., \& Gaeth, G. J. (1990). Assessing the Institutional Choice Process of StudentAthletes. Research Quarterly for Exercise and Sport, 61(1), 85-92.

[6] Finley, P., \& Fountain, J. J. (2008). An application of means-end theory to analyze the college selection process of female athletes at an NCAA division II--university. The Sport Jou rnal, 11(2).

[7] Fulks, D.L. (2000). Revenues and expenses of divisions II and III intercollegiate athletics programs: Financial trends and relationships-1999. Indianapolis, IN: National Collegiate Athletic Association

[8] Franklin, B. (2006). College athletics as a model for promoting academic integrity in higher education. Mid-Western Educational Researcher, 19(1), 15-23. Retrieved from http://web.ebs cohost.com.proxy.lib.odu.edu/.

[9] Gabert, T., Hale, J., \& Montalvo, G. (1999). Differences in college choice factors among fresh man student-athletes. The Journal of College Admission, 164, 20-29.

[10] Goss, B. D., Jubenville, C. B., \& Orejan, J. (2006). An examination of influences and factors on the institutional selection processes of freshmen student-athletes at small colleges and univer sities. Journal of Marketing for Higher Education, 16(2), 105-134.

[11] Hossler, D., \& Gallagher, K. (1987). Studying student college choice: A three phase model and the implications for policymakers. College and University, 62(3), 207-222.

[12] Johnson, G. R., Jubenville, C., \& Goss, B. (2009). Using institutional selection factors to develop recruiting profiles: Marketing small, private colleges and universities to prospective student athletes. Journal of Marketing for Higher Education, 19(1), 1-25. 
[13] Kankey, K., \& Quarterman, J. (2007). Factors influencing the university choice of NCAA Division I softball players. The Smart Journal, 3(2), 35-49.

[14] Klenosky, D. B., Templin, T. J., \& Troutman, J. A. (2001). Recruiting student athletes: A meansend investigation of school-choice decision making. Journal of Sport Management, 15(2), 95106.

[15] Letawsky, N. R., Palmer, C. J., \& Schneider, R. G. (2005). Factors influencing the college selection process of male and female student-athletes. International Journal of Sport Management, 6(1), 84-97.

[16] Letawsky, N. R., Schneider, R. G., Pedersen, P. M., \& Palmer, C. (2003). Factors influencing the college selection process of student-athletes: Are their factors similar to non-athletes? College Student Journal, 37(4), 604-610.

[17] Mathes, S., \& Gurney G. (1985). Factors in student athletes' choices of colleges. Journal of College Student Personnel, 26, 327-333.

[18] National Collegiate Athletic Association. (2016a). NCAA rules and bylaws. Retrieved from https://www.ncaapublications.com/s-13-Manuals.aspx

[19] National Collegiate Athletic Association. (2016b). NCAA student-athletes. Retrieved from http://www.ncaa.org/student-athletes.

[20] National Collegiate Athletic Association. (2016b). Division II facts and figures. Retrieved from http://www.ncaa.org/division-ii-facts-and-figures.

[21] National Collegiate Athletic Association. (2015). NCAA sports sponsorship and participation rates report. Retrieved from http://www.ncaa.org/sites/default/files/Participation\%20Rates\%20 Final.pdf.

[22] Pampaloni, A. M. (2010). The influence of organizational image on college selection: what students seek in institutions of higher education. Journal of Marketing for Higher Educat ion, 20(1), 19-48. doi: 10.1080/08841241003788037

[23] Pauline, J. (2010). Factors influencing college selection by NCAA Division I, II, and III lacrosse players. The ICHPER-SD Journal of Research in Health, Physical Education, Recreation, Sport \& Dance, 5(2), 62-69.

[24] Pauline, J. (2012). Factors influencing college selection by NCAA Division I, II, and III soccer players. International Journal of Sport Management 13(1), 87-103.

[25] Pauline, J. S., Pauline, G. A., \& Stevens, A. J. (2004). Influential factors in the college selection process of baseball student-athletes. Journal of Contemporary Athletics, 1,153-166.

[26] Popp, N., Pierce, D., \& Hums, M. A. (2011). A comparison of the college selection process for international and domestic student-athletes at NCAA Division I universities. Sport Management Review, 14(2), 176-187.

[27] Skaff, V. S. (1992). Factors influencing college selection of male student athletes participating in three intercollegiate sports at Slippery Rock University. Unpublished master's thesis. Slippery Rock University, Slippery Rock, PA.

[28] Stinson, J.L. \& Howard, D.R. (2007). Athletic success and private giving to athletic and academic programs at NCAA institutions. Journal of Sport Management, 21(2), 235-264.

[29] Stinson, J.L. \& Howard, D.R. (2004). Scoreboards vs. mortarboards: Major donor behavior and intercollegiate athletics. Sport Marketing Quarterly, 13(2), 129 - 140.

[30] Toma, J. D., \& Cross, M. E. (1998). Intercollegiate athletics and student college choice: Explor ing the impact of championship seasons on undergraduate applications. Research in Higher Edu cation, 39(6), 633-661.

[31] Tucker, I. B. (2004). A reexamination of the effect of big-time football and basketball success on graduation rates and alumni giving rates. Economics of Education Review, 23(4), 655- 661.

[32] Umbach, P.D., Palmer, M. M., Kuh, G. D., \& Hannah, S. J. (2006) Intercollegiate athletes and effective educational practices: Winning combination or losing effort. Research in Higher Education, 47(6), Retrieved from http://nsse.iub.edu/pdf/research_papers/athletes.pdf. 
Jon Lim et al.

[33] Upthegrove, T. R., Roscigno, V. J., \& Charles, C. Z. (1999). Big money collegiate sports: Racial concentration, contradictory pressures, and academic performance. Social Science Quarterly, 80(4), 718-737.

[34] Vermillion, M., \& Spears, G. (2012). College choice factors for Division I athletes at an urban university. The Sport Journal, 15(1).

[35] Wieberg, S. (2008, January 13). Study: College athletes are full-time workers. USA Today. Retrieved from http://www.usatoday.com 